\title{
The Swedish population of Lesser White-fronted Goose Anser erythropus - supplemented or re-introduced?
}

\author{
Det svenska beståndet av fjällgås Anser erythropus - förstärkt eller \\ återinplanterat?
}

ÅKE ANDERSSON \& NIKLAS HOLMQVIST

\begin{abstract}
We have investigated historical records of observations of Lesser White-fronted Goose Anser erythropus of the original Fennoscandian population in the area in Sweden where captive-reared goslings of the same species were released during 1981-1999. The release project has earlier been regarded as a re-introduction project. The data in this review include reports from many sources and we can present earlier unpublished observations from the area. The large number of observations of birds from the

Fennoscandian population proves that the release of goslings in the actual area was a supplementation of a small but extant population and not a re-introduction.

Ake Andersson, Ringgatan 39C, SE-752 17 Uppsala, Sweden.ake_a@tele2.se

Niklas Holmquvist, Öster Malma, SE-611 91 Nyköping, Sweden.Niklas.holmqvist@jagareforbundet.se
\end{abstract}

\section{Introduction}

From the 1950 s to the 1990 s the breeding population of Lesser White-fronted Goose Anser erythropus in Sweden decreased from some thousand pairs to about 10 pairs in 1990 (von Essen 1999). During the following decade the decline continued. The trend was similar in Norway, Finland and western Russia (Kear 2005, Jones at al. 2008) with a significant and continuous decrease. The species is probably extinct in Finland today.

In the late 1970s, Lambart von Essen at the Swedish Association for Hunting and Wildlife Management started to prepare a release programme. During the period 1981-1999, 348 geese were released in a traditional breeding area of the species in Swedish Lapland (Andersson \& Larsson 2006). No captive-reared geese have been released after 1999.

The release activities have been labelled re-introduction in earlier works (see for example von Essen 1996, 1999) and this opinion and terminology has survived in later reports (Andersson \& Larsson 2006). In this review we analyse and evaluate the available information from the period just before and after the start of the release, in order to elucidate whether or not birds from the original population occurred in the area.

\section{Materials and methods}

We have compiled historical data including records found in archives as well as results from interviews. The Swedish Ornithological Society has collected avifaunistic information on a national basis since 1975 and published it in a yearly report (e.g. Risberg 1976). The archive emanating from Lambart von Essen includes correspondence and notes from interviews with ornithologists as well as people inhabiting in the mountain area. A special effort was made by Per Hansson (2006) who listed all known observations of the species in Västerbotten county. A similar compilation of published data was done by Rolf Gustafsson for Norrbotten county. The information from these two works is available in the data base of the Species Information Center (www. artportalen.se/birds/), except records in the breeding area, which are excluded because of security reasons.

In this review we focus primarily on findings made within a $50 \mathrm{~km}$ radius from the places where the releases took place. From this area we only accepted observations where the status of the birds could be determined (released birds or birds of Fennoscandian origin). All findings before summer 1981, adult birds before spring 1982, breeding birds before 1983 and un-ringed breeding birds 
Table 1. Observations of Lesser White-fronted Geese 1975-1984 within or close to the breeding areas in Lycksele and Pite lappmark in Swedish Lapland under circumstances where presence of released birds can be excluded. Under Reference we list the original source. Svalan I (Sv I) is the database where sensitive observations are omitted, while Svalan II (Sv II) includes classified data. Nr refers to the position of the observation on the map (Figure 1).

Observationer av fjällgäss 1975-1984 inom eller nära häckningsområden i Lycksele och Pite lappmarker under omständigheter då förekomst av utsläppta fåglar kan uteslutas. Under Reference listas ursprungskällan. Svalan I (Sv I) är databasen utan och Svalan II (Sv II) med sekretessklassade observationer. Nr anger plats för observationen på kartan i Figur 1.

\begin{tabular}{|c|c|c|c|c|c|}
\hline $\mathrm{Nr}$ & Date & Observation & $\begin{array}{l}\text { Within } \\
\text { Inom } \\
0-30 \mathrm{~km}\end{array}$ & $\begin{array}{l}\text { Within } \\
\text { Inom } \\
31-50 \mathrm{~km}\end{array}$ & Reference \\
\hline 1 & 1975-06-18-21 & 1 pair & \multicolumn{2}{|c|}{ Båssjosjaure, Tjålmejaure } & H. Berglund, LvE arch., Sv II \\
\hline 2 & 1976-05-29 & 2 & \multicolumn{2}{|c|}{ Delta in Ammarnäs } & V. Olsson, Sv I \\
\hline 3 & $1976-07-25-31$ & $2 \mathrm{ad}+2 \mathrm{imm}$ & \multicolumn{2}{|l|}{ Giertos, Tjålmejaure } & H. Berglund, LvE arch., Sv II \\
\hline 4 & 1976-07-30 & $2 \mathrm{ad}+4$ pull & \multicolumn{2}{|l|}{ Giertos, Tjålmejaure } & H. Berglund, LvE arch., Sv II \\
\hline 5 & 1978-06-30 & Breeding record & \multicolumn{2}{|l|}{ d Vaggejukke, Svaipa } & L. von Essen, LvE arch., Sv II \\
\hline 6 & $1978-07-17$ & Heard & \multirow{2}{*}{\multicolumn{2}{|c|}{$\begin{array}{l}\text { Västra Tjålmejaure } \\
\text { Västra Tjålmejaure }\end{array}$}} & P. Oppentocht, LvE arch., Sv II \\
\hline 7 & $1978-07-26$ & $2 \mathrm{ad}$ & & & P. Oppentocht, LvE arch., Sv II \\
\hline 8 & 1978 & \multirow{2}{*}{$\begin{array}{l}\text { A few pairs left Björkfjället } \\
\text { A few pairs left }\end{array}$} & \multicolumn{2}{|l|}{ t Björkfjället } & E. Norén, Sv II \\
\hline 9 & 1978 & & & $\begin{array}{l}\text { Tjahthsavaggie, } \\
\text { Birdejaure }\end{array}$ & E. Norén, Sv II \\
\hline 10 & 1978 & A few pairs left & & $\begin{array}{l}\text { Buorguokjávrrie, } \\
\text { Biellojaure }\end{array}$ & E. Norén, Sv II \\
\hline 11 & 1979 breeding season & 1 pair & Suolojaure & & P.-H. Lango, LvE notebook 8 \\
\hline 12 & 1979-07-05 & $1 \mathrm{ad}+4$ pull & S Vielparnjarga & & P. Oppentocht, LvE arch., Sv II \\
\hline 13 & 1979-07-12 & $3 \mathrm{ad}$ & Vielparnjarga & & P. Oppentocht, LvE arch., Sv II \\
\hline 14 & 1980-05/06 & 2 & Delta in Yraft, Laisälve & & W. Thorfe, LvE arch., Sv I \\
\hline 15 & 1980 breeding season & 1 & Suolojaure & & P.-H. Lango, LvE notebook 8 \\
\hline 16 & 1980-06-11 & 1 & Svaipa & & LvE arch. \\
\hline 17 & $1980-06-23$ & 5 & Båssjosjaure, Tjålmejau & & R. Nordin, Sv I \\
\hline 18 & $1980-08-27$ & $13 \mathrm{ad}$ & Luspasjaure & & E. Norén, Västerbotten County adm arch. \\
\hline 19 & $1981-06-23$ & $6 \mathrm{ad}$ & SW Luspasjaure & & L. Strömgren, Report to $\AA A$ \\
\hline 20 & 1981-08-09 & 1 pair $+5 \mathrm{im}$ & Luspasjaure & & P. Klaesson, LvE arch., Sv. II \\
\hline 21 & 1982-05-29-06-11 & Up to $10 \mathrm{ad}$ & Delta in Ammarnäs & & L. Gustafsson, Sv I \\
\hline 22 & $1982-06-26$ & $10 \mathrm{ad}$ & Tjålmejaure & & P. Svensson, LvE arch., Sv II \\
\hline 23 & 1984-07-10 & $2 \mathrm{ad}+2$ pull & W Vielparnjarga & & P. Oppentocht, LvE arch., Sv II \\
\hline
\end{tabular}

before 1985 were categorized as birds of Fennoscandian origin (Table 1, Figure 1). Observations reported from areas situated $50-100 \mathrm{~km}$ from the release area are shown in Table 2.

The first release of young Lesser White-fronted Geese took place in July 1981 (11 goslings). Theoretically, these birds could breed already in 1983 and their possible descendents in 1985. Even though it is rare that the species breeds successfully at the age of two years (Owen 1980, del Hoja et al. 1992, Kear 2005), we consider 1983 as the first year for possible breeding of released (colourringed) geese, and 1985 in the case of their off- spring, in order to prevent any misinterpretation of the data given in the archives. Releases were made almost annually in 1981-1999, all with colour-ring marked birds.

\section{Results}

In total, 23 records of birds from the original population at, or close to, breeding habitat within a distance of $50 \mathrm{~km}$ from the release localities were found (Figure 1 and Table 1). From a larger area (51-100 km from the release sites, Table 2) there are reports verifying breeding of the species 


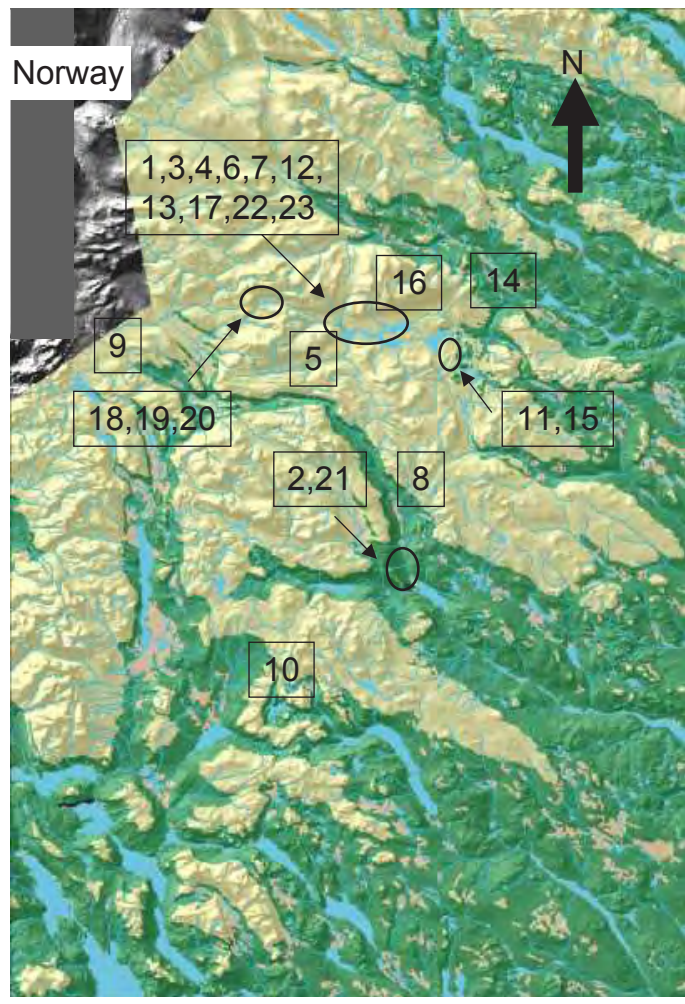

Figure 1. Map showing position of observations of Lesser White-fronted Goose $(n=23)$ in or close to the area where captive-bred geese where released during the years 19811999. All observations included were made between the years 1975 and 1984 and only include birds from the original Fennoscandian population. The numbers refers to position number $(\mathrm{Nr})$ in Table 1.

Karta över fjällgåsobservationer ( $n=23)$ i eller nära området där fåglar uppfödda i fångenskap släpptes ut åren 19811999. Alla medtagna observationer gjordes åren 1975-1984 och omfattar endast fåglar från den ursprungliga fennoskandiska populationen. Siffrorna hänvisar till numreringen $i$ Tabell 1 .

at some localities until 1988 or 1991 and observations of adults until 1998. Considering the historical records of occurrence in these areas and the site fidelity of released geese, it is most likely that the main part of these observations consists of geese from the original Fennoscandian population.

\section{Discussion}

The presented data show that a small breeding population consisting of birds from the original Fennoscandian population of Lesser White-fronted geese was still present when the release of captive-reared gooslings started in 1981. Individual birds from this indigenous population living in the western part of the release area survived at least until 1984, but probably even longer considering the longevity of Lesser White-fronted Geese. For example, Piet Oppentocht (in litt.) who visited the western part in 1978-1988, recorded the species or its excrements also in 1985 (including observation of one unringed adult, three adults and one observation of a downy young without adults). In 1986 and 1987 geese were heard calling and excrements found. In 1988 (the last visit) one single downy young was seen without parents. Therefore, it is likely that Lesser White-fronted Geese continued to breed at this site. However, we do not include these data since we can not exclude that these birds could be descendants of released individuals.

With exception of the western parts of the release area there are few observations recorded in the archives. Hence, we cannot be sure that birds of the original population were still breeding in the whole area when releases commenced in 1981. From the eastern part there are very few known records. A nest was reported in 1983, but we cannot rule out that it was wrongly identified or a result of breeding of released birds and therefore we exclude this record.

As shown in Table 2, at longer distances (51$100 \mathrm{~km}$ ) from the release area, there are reports that could indicate even longer presence of birds of Fennoscandian origin after the releases started. Table 2 also includes observations of birds in or near suitable breeding grounds from adjacent areas in Norway (Øien \& Aarvak 1993, Gjershaug et al 1994). But the origin of these birds cannot be determined due to the possible presence of un-ringed descendants of released birds. However, these findings give further support to the overall picture of a scarce but widespread breeding population in the mountain area used for release of captive-reared goslings.

Besides observations in the breeding areas there are also reports showing that the migration route along the Skellefte River was still used by Lesser White-fronted Geese during the 1970s and the early 1980s (Hansson 2006). Flocks were seen during spring 1976 and 1981 (in both cases with adults as well as $2 \mathrm{~K}$ subadults) along this migration route leading to the mountain area where the releases started in 1981.

We conclude that the release of captive-reared Lesser White-fronted Geese started at a time when breeding birds of Fennoscandian origin still inhabited the area. Thus, according to the IUCN guide- 
Table 2. Observations of Lesser White-fronted Geese during 1985-1998 at a distance of 50-100km from the area used for release of captive bred goslings. Only observations close to or within suitable or known breeding areas are included. All released captive-reared birds were marked with colour rings, but their offspring lack rings.

Observationer av fjällgäss under perioden 1985-1998 som gjorts på ett avstånd av 50-100 km från området som användes för utsättning av unga fjällgäss. Alla observationer är giorda inom eller nära kända eller lämpliga häckningsplatser. Samtliga fjällgäss som var uppfödda i fängenskap och släpptes ut bar färgringar, men deras avkommor saknar ringar.

\begin{tabular}{|c|c|c|c|c|}
\hline Date & Observation & Locality & Distance & Reference \\
\hline 1988-07-01 & $\begin{array}{l}\text { Un-ringed pair with } 3 \\
\text { goslings Omärkt par med } \\
\text { tre ungar }\end{array}$ & $\begin{array}{l}\text { Södra Storfjället, } \\
\text { northern part }\end{array}$ & $85 \mathrm{~km}$ & P. Risberg, LvE arch. \\
\hline 1989-06-27 & $\begin{array}{l}4 \text { adult ( } \geq 3 \text { without rings) } \\
\text { two consecutive days } \\
4 \text { ad två efterföljande dagar }\end{array}$ & $\begin{array}{l}\text { Södra Storfjället, } \\
\text { northern part }\end{array}$ & $85 \mathrm{~km}$ & P. Risberg, LvE arch. \\
\hline 1994-06-24 & Feathers Fjädrar & $\begin{array}{l}\text { Södra Storfjället, } \\
\text { northern part }\end{array}$ & $85 \mathrm{~km}$ & L. von Essen, LvE arch. \\
\hline 1997-07-06 & $2 \mathrm{ex}$ & $\begin{array}{l}\text { Södra Storfjället, } \\
\text { northern part }\end{array}$ & $85 \mathrm{~km}$ & Molin, LvE arch. \\
\hline $1998-05-16+18$ & $5 \mathrm{ex}$ & Krutvattnet, Ström & $100 \mathrm{~km}$ & U. Åkesson, Sv I \\
\hline $1998-05-27$ & $3 \mathrm{ex}$ & Krutvattnet, Ström & $100 \mathrm{~km}$ & U. Åkesson, Sv I \\
\hline 1986-06-20 & $3 \mathrm{ex}$ & Ältsvattnet & $50 \mathrm{~km}$ & B. Liehr, LvE arch., Sv II \\
\hline 1986-08-11 & $>1$ heard hörd & $\begin{array}{l}\text { Gingeljaure, W Övre } \\
\text { Ältsvattnet }\end{array}$ & $50 \mathrm{~km}$ & $\begin{array}{l}\text { E. Norén, Västerbotten } \\
\text { county adm. arch. }\end{array}$ \\
\hline $1988-07-16$ & $\begin{array}{l}\text { Suspected brood } \\
\text { Misstänkt kull }\end{array}$ & Ältsvattnet & $50 \mathrm{~km}$ & L. von Essen, LvE arch. \\
\hline $1985-1992$ & $\begin{array}{l}\text { Suspected and proofed } \\
\text { breeding until } 1991 \text { (1992) } \\
\text { Misstänkt och säkerställd } \\
\text { häckning till } 1991 \text { (2992) }\end{array}$ & $\begin{array}{l}\text { Norway: Grane, } \\
\text { Hattfjelldal and Rana } \\
\text { communities }\end{array}$ & $50-100 \mathrm{~km}$ & $\begin{array}{l}\text { Øien, I. J. \& T. Aarvak } 1993 \\
\text { Gjershaug, J. O. et al. } 1994\end{array}$ \\
\hline
\end{tabular}

lines and terminology (IUCN 1998) the releases should not be labelled as a re-introduction but instead fulfil the criteria for population "re-inforcement" or "supplementation".

\section{Acknowledgements}

We thank Torsten Larsson, Per Sjögren-Gulve and Bo Fagerström for constructive input to this paper. The Swedish Lesser White-fronted Goose program is financed by Swedish Environmental Protection Agency, Norrbotten county, WWF Sweden, Stiftelsen Våtmarksfonden, Stiftelsen Sveriges Vildnad, Alvins fond and Göran Gustafssons stiftelse

\section{References}

Andersson, Å. \& Larsson, T. 2006. Reintroduction of Lesser White-fronted Goose Anser erythropus in Swedish Lapland. Pp. 635-636 in Waterbirds around the world. (Boere, G.C., Galbraith, C.A. \& Stroud, D.A., eds.).

del Hoyo, J., Elliott, A. \& Sargatal, J. eds. 1992. Handbook of the Birds of the World. Vol. 1. Lynx Edicions, Barcelona. von Essen, L. 1996. Reintroduction of lesser white-fronted geese (Anser erythropus) in Swedish Lapland (19811991). In: Proceedings of the Anatidae 2000 Conference, Strasbourg, France, 5-9 December 1994 (Birkan, M., van Vessem, J., Havet, P., Madsen, J., Trolliet, B. \& Moser, M. eds.). Gibier Faune Sauvage 13: 1169-1180.

von Essen, L. 1999. The Swedish reintroduction project on Lesser White-fronted Geese. Pp. 22-23 in Fennoscandian Lesser White-fronted Goose conservation project. Annual report 1998. WWF Finland Report 10 \& Norwegian Ornithological Society, NOF Rapportserie no 1-2000 (Tolvanen, P., Øien, I.J. \& Ruokalinen, K. eds.).

Gjershaug, J.O., Thingstad, P.G., Eldøy, S. \& Byrkjeland, S. (red.) 1994. Norsk fugleatlas. Norsk Ornitologisk Forening. Klæbu.

Hansson, P. 2006. Fjällgåsobservationer i Sverige rapporterade till Artportalen. Unpublished review of historical observations in Sweden.

IUCN Species Survival Commission. 1998. Guidelines for Re-introductions. IUCN, Gland, Switzerland.

Jones, T., Martin, K., Barov, B. \& Nagy, S. (compilers). 2008. International Single Species Action Plan for the Conservation of the Lesser White-fronted Goose (Western Palearctic Population) Anser erythropus. AEWA Technical Series No. 36. Bonn, Germany.

Kear J. 2005. Ducks, Swans and Geese. Volume 1. Oxford University Press, Oxford, UK. Pp 286-288. 
Øien, I.J. \& Aarvak, T. 1993. Status for Dverggås Anser erythropus i Fennoskandia. Norsk Ornitologisk Forening. Owen, M. 1980. Wild geese of the world. London.

Risberg, L. 1976. Fågelrapport för 1975. Vår Fågelvärld 35: 312-328.

\section{Sammanfattning}

I denna artikel redovisas fynd av fjällgäss, de flesta tidigare opublicerade, från den ursprungliga, fennoskandiska, populationen i Sverige mellan åren 1975 och 1984. Observationerna är gjorda i eller nära det område som användes för utsättningar av uppfödda fjällgåsungar inom Projekt Fjällgås under åren 1981-1999. Vi kan redovisa 21 fynd inom en radie av $30 \mathrm{~km}$ från utsättningsområdet och ytterligare två inom 31-50 kms radie, där vi kunnat utesluta att det rör sig om fåglar som härstammar från projektet (Tabell 1 och Figur 1). I Tabell 2 redovisas även 10 fynd av fjällgäss på kända eller lämpliga häckningsplaster mellan åren 1985-1998 dvs. efter det att utsättningar av fjällgäss startat. Men beroende på avståndet till området där utsättningar gjordes och andra faktorer, t.ex. att de vuxna fåglarna var omärkta, så bedöms även flertalet av dessa observationer gälla fåglar från den ursprungliga fennoskandiska populationen. Sammanställningen av dessa fynd visar att det häckade fjällgäss av den ursprungliga fennoskandiska populationen i området som användes för utsättningarna av fjällgäss i Projekt Fjällgås när dessa startade 1981 och att det fortsatte att häcka fåglar från denna population i området efter det att utsättningarna startade. Utsättningen av uppfödda fjällgäss inom Projekt Fjällgås har tidigare setts som ett reintroduktionsprojekt. Fynden som presenteras i denna artikel visar att utsättningarna istället är att betrakta som en förstärkning av ett befintligt bestånd enligt IUCNs kriterier för artbevarandeprojekt. 